\title{
The effect of the heat treatment on the crosslinking of epoxy resin for aviation applications
}

\author{
Mateusz Mucha ${ }^{1),}$ (), Tomasz Sterzyński²), Aneta Krzyżak1) \\ DOI: dx.doi.org/10.14314/polimery.2020.11.4
}

\begin{abstract}
We have investigated the MGS L285 epoxy laminating resin system, used in aviation applications. A number of tests were carried out, namely Dynamic Mechanical Analysis (DMA), Differential Scanning Calorimetry (DSC), tensile testing, three-point bending flexural testing, Charpy impact testing, Shore D hardness, density measurements and Fourier-Transform Infrared spectroscopy (FT-IR). Moreover, the tensile toughness $U_{\mathrm{TT}}$, the brittleness $B$ and the linear isobaric thermal expansivity $\alpha_{\mathrm{L}}$ were calculated. The samples were subjected to heat treatment in the temperatures of 50,60 and $80^{\circ} \mathrm{C}$ for 15 hours or were stored in room temperature. Glass transition temperature, hardness, density as well as other properties were observed to rise along with the increasing heat treatment temperature, suggesting the validity of applications of Voronoi-Delaunay structural analysis to polymer science. On the other hand, properties such as brittleness, toughness and impact strength exhibited a non-linear course of changes as a function of the heating temperature.
\end{abstract}

Keywords: epoxy resin, heat treatment, crosslinking, aviation.

\section{Wpływ wygrzewania na sieciowanie żywicy epoksydowej przeznaczonej do zastosowań w lotnictwie}

Streszczenie: Badano laminującą żywicę epoksydową MGS L285 przeznaczoną do zastosowań w lotnictwie. Przeprowadzono dynamiczną analizę mechaniczną (DMA), skaningową kalorymetrię różnicową (DSC), statyczną próbę rozciągania, zginanie trójpunktowe, badanie młotem Charpy'ego, pomiary twardości metodą Shore'a D, pomiary gęstości, zarejestrowano także widma metodą skaningowej spektroskopii transformatorowej Fouriera (FT-IR). Obliczono wartości wiązkości $U_{T T}$ kruchości $B$ i izobarycznej rozszerzalności termicznej $\alpha_{\mathrm{L}}$. Próbki wygrzewano w temperaturze 50, 60 lub 80 stopni Celsjusza przez $15 \mathrm{~h}$ lub przechowywano $\mathrm{w}$ temperaturze pokojowej. W odniesieniu do dużej części badanych właściwości zaobserwowano ich poprawę wraz z rosnącą temperaturą wygrzewania. Korelacja temperatury zeszklenia, twardości i gęstości polimerów wskazuje na słuszność zastosowania w badaniu wolnych objętości analizy strukturalnej opartej na triangulacji Delone i diagramach Woronoja. W wypadku właściwości, takich jak: kruchość, wiązkość i udarność stwierdzono nieliniowy przebieg zmian w funkcji temperatury wygrzewania.

Słowa kluczowe: żywica epoksydowa, wygrzewanie, sieciowanie, lotnictwo.

Currently, the composites based on epoxy resin are regarded as most important material used in aviation, for structural elements [1-9], including aircraft skin [10, 11]. In order to meet increasing expectations, more and more research is being conducted to modify the properties of the resin by adding fillers [12-16], including the increasingly popular nanofillers [17-25]. An important challenge for all technical applications of epoxy resin based com-

\footnotetext{
1) Military University of Aviation, Faculty of Aviation, Dywizjonu 303 35, 08-521 Dęblin, Poland.

2) Poznan University of Technology, Polymer Division, Institute of Materials Technology, Piotrowo 3, 61-138 Poznań, Poland.

*) Author for correspondence: m.mucha@law.mil.pl
}

posites, particularly aviation constructions, is the need to manufacture materials with significantly reduced flammability [26-29]. However, fillers can reduce the gel time of the resin [30,31], and therefore alter the manufacturing process. For example, it was found that water contained in fillers may cause an acceleration of the resin/hardener reaction [32]. On the other hand, for some epoxy resins, the heat treatment is necessary to achieve the properties required in aviation $[33,34]$.

In order to properly assess the effect of the filler on the resin, it is necessary to know thoroughly the crosslinking process of the neat resin [35-42]. In particular, it is advisable to determine the effect of heat treatment on the resin properties [43-46]. For example, in case of the concrete based on epoxy resin mixed with isophorone diamine (IPDA) hardener, higher curing temperature (in a range to 
$60^{\circ} \mathrm{C}$ ) resulted in an improved modulus of elasticity and ultimate compressive, as well as flexural strength [47].

One of usually applied technique to study the crosslinking of the resin is to determine its hardness. The Dynamic Mechanical Analysis (DMA) and Differential Scanning Calorimetry (DSC) allow to define the thermal properties of the resin, in particular the region of the glass transition $T_{g}$ [48-52]. The typical Fourier Transformed InfraRed spectra for epoxy resin are known, so any additional peaks obtained during FT-IR-measurements will inform about the unusual behavior of the material [53, 54].

The subject of the study is the MGS L285 laminating resin system, that is commercially available and commonly used in aviation [55]. According to the technical specification provided by the manufacturer, after a heat treatment at $50-55^{\circ} \mathrm{C}$, the system meets the standards for gliders and motor gliders, and after a heat treatment at $80^{\circ} \mathrm{C}$, it satisfies the standards for motor planes [32]. The purpose of this work is to obtain a better understanding of the process of crosslinking of the resin, and particularly the influence of post-heat treatment on the cured epoxy resin.

\section{EXPERIMENTAL PART}

\section{Materials}

The objective of the studies was EPIKOTE resin MGS LR 285 and EPIKURE curing agent MGS LH 285. Laminating resin L285 is a mixture of epoxy resin (number average molecular weight $\leq 700$ ), which is a reaction product of bisphenol-A (epichlorhydrin) (50-75 wt \%) and 1,2,3-propanetriol, glycidyl ethers (50-75 wt \%). H285 hardener is a mixture of 3-aminomethyl-3,5,5-trimethylcyclohexylamine (75-90 wt \%), phenol, 4,4'-(1-methylethylidene)bis-, polymer with 5-amino-1,3,3-trimethylcyclohexanemethanamine and (chloromethyl)oxirane (5-13 wt \%), benzyl alcohol (5-10 wt \%), 4-nonylphenol, branched (0-1.1 wt \%), 3 -aminopropyltriethoxysilane (0-1 wt \%). The information of basic physical and chemical properties of the resin and the hardener are presented in Table 1 [32].

\section{Sample preparation}

After mixing the resin with the amine curing agent, samples were cast into PTFE molds for 24 hours. Then, one out of four groups of samples was stored at room temperature of $23^{\circ} \mathrm{C}$, and the other three groups were subjected to heat treatment at 50,60 and $80^{\circ} \mathrm{C}$, respectively. The temperature range of up to $80^{\circ} \mathrm{C}$ was based on the manufacturer's recommendations, although it can be estimated that higher temperature value would result in a higher degree of conversion of functional groups of the polymer [56].

The majority of samples were prepared with $100: 40$ mass ratio recommended by the manufacturer. However, in order to have more insight in the curing process, specimens for hardness and density testing were also prepared with $100: 30$ and $100: 50$ ratios.

\section{Methods of testing}

\section{Dynamic mechanical analysis}

The DMA allowed determining the complex modulus, in a range of temperatures from ambient conditions to $150^{\circ} \mathrm{C}$. Plots of storage and loss modulus obtained with the heating rate of $2.0^{\circ} \mathrm{C} / \mathrm{min}$, were used to locate the glass transition temperature region and $T_{g \mathrm{DMA}^{\prime}}$ as well as determining storage modulus $E^{\prime}$ at room temperature $\left(25^{\circ} \mathrm{C}\right)$.

DMA testing was performed using the Anton Paar MCR301 rotational rheometer. Specimens of a rectangular form $\left[50.0 \times 10.0 \times 3.0\left(\mathrm{~mm}^{3}\right)\right.$ nominal dimensions] were analyzed by torsion, one per each of the four heat treatment temperatures. The sinusoidal stress at frequency $f=1.0 \mathrm{~Hz}$ (typical value for DMA [57]) as a function of time was imposed, reaching a peak value for normal force of $1.0 \mathrm{~N}$, applied in the grip at a distance from the axis of rotation. This resulted in a cyclic deformation of the sample. The number of data points was 281 per sample.

\section{Differential scanning calorimetry}

The DSC was used to determine the glass transition temperature $T_{g \text { DSC }}[49,57-64]$. One sample per each heat treatment temperature was tested on Differential Scanning Calorimeter Netzsch Phoenix 204 F1 apparatus, in accordance with ISO 11357 standard [65]. The heating and cooling rate were set at $10.0^{\circ} \mathrm{C} / \mathrm{min}$ and the temperature range between -60 and $200^{\circ} \mathrm{C}$.

\section{Tensile testing}

The tensile testing was carried out to obtain the values of tensile strength, Young's modulus $E_{t}$, the ultimate tensile strength $\sigma_{\mathrm{m}^{\prime}}$ the tensile strain at tensile strength $\varepsilon_{\mathrm{m}^{\prime}}$ the fracture strength $\sigma_{\mathrm{b}^{\prime}}$ and the strain at break $\varepsilon_{\mathrm{b}}$ based on the stress-strain $(\sigma-\varepsilon)$ curves. Moreover, the area underneath the stress-strain curve was calculated

$\mathrm{T}$ a b 1 e 1. Properties of MGS L285 epoxy resin and $\mathrm{H} 285$ hardener measured at $25^{\circ} \mathrm{C}$ [32]

\begin{tabular}{c|c|c|c|c|c|c}
\hline & $\begin{array}{c}\text { Density } \\
\mathrm{g} / \mathrm{cm}^{3}\end{array}$ & $\begin{array}{c}\text { Viscosity } \\
\mathrm{mPa} \cdot \mathrm{s}\end{array}$ & $\begin{array}{c}\text { Epoxy } \\
\text { equivalent } \\
\text { g/equivalent }\end{array}$ & $\begin{array}{c}\text { Epoxy value } \\
\text { equivalent/100 g }\end{array}$ & $\begin{array}{c}\text { Amine value } \\
\mathrm{mgKOH} / \mathrm{g}\end{array}$ & $\begin{array}{c}\text { Refractory index } \\
\text { Laminating } \\
\text { resin L285 } \\
\text { Hardener H285 }\end{array}$ \\
\hline
\end{tabular}


to obtain the tensile toughness $U_{\mathrm{TT}}$. The values of $E^{\prime}$ and $\varepsilon_{\mathrm{b}}$ were used to calculate the brittleness $B$, to evaluate the linear isobaric thermal expansivity $\alpha_{\mathrm{L}}$.

The tensile properties of 40 bone-type (1BA) samples (10 per each heat treatment temperature) were determined in accordance with ISO 527 standard on Zwick/ Roell Z5.0 machine, with the test speed of $1 \mathrm{~mm} / \mathrm{min}$.

The toughness $U_{\mathrm{TT}}$ was calculated in accordance with Eq. (1) defined in [66]:

$$
U_{T T}=\int_{0}^{\varepsilon_{b}} \sigma \delta \varepsilon
$$

The brittleness $B$ was determined in accordance with Eq. (2) defined in [67]:

$$
B=1 /\left(E^{\prime} \cdot \varepsilon_{\mathrm{b}}\right)
$$

The isobaric thermal expansivity $\alpha_{\mathrm{L}}$ was calculated in accordance with Eq. (3) defined in [68]:

$$
\alpha_{\mathrm{L}}=104 \cdot B^{0.132}
$$

\section{Flexural testing}

The three-point bending flexural testing provided values of the modulus of elasticity in bending $E_{\rho}$ the maximum flexural stress $\sigma_{\mathrm{fM}}$ and the failure strain $\varepsilon_{\mathrm{fM}}$. The flexural properties of 40 rectangular form $\left[80.0 \times 10.0 \times 4.0\left(\mathrm{~mm}^{3}\right)\right.$ nominal dimensions] samples (10 per each heat treatment temperature) were determined in accordance with ISO 178 standard, by means of the Zwick/Roell Z5.0 universal testing machine, operating by test speed of $2 \mathrm{~mm} / \mathrm{min}$.

\section{Impact testing}

The amount of energy absorbed by material at fracture, was determined by means of the Charpy impact testing. The measurements of Charpy impact properties of 40 rectangular form $\left[80.0 \times 10.0 \times 4.0\left(\mathrm{~mm}^{3}\right)\right.$ nominal dimensions $]$ samples (10 per each heat treatment temperature) were per- formed on Galdabini - Impact 25 tester, in accordance with ISO 179-1 standard. The Charpy striker, with 7.5 J energy and $1 \mathrm{fU}$ method were set for the testing.

Values of $B$ and $U_{C}$ were compared with Eq. (4) defined in [69]:

$$
U_{C}=a_{C}+1 / \tanh \left(b_{C} \cdot B\right)
$$

where parameters $a_{C}=-0.640$, and $b_{C}=1.63$ were calculated by Brostow et al. in [69].

\section{Hardness testing}

In order to determine Shore D hardness, in accordance with ISO 868 standard, the set of 10 samples was tested per each heat treatment temperature, as well as each resin/hardener mass ratio.

\section{Density measurements}

The density measurements were performed for one sample per each heat treatment temperature, as well as each resin/hardener mass ratio, on a precision laboratory scale Mettler Toledo XSE205, with an accuracy of $0.01 \mathrm{mg}$. Also the immersed solid body method was applied. As a liquid, distilled water at a room temperature was used.

\section{FT-IR}

One sample per each of the four heat treatment temperatures was examined on Jasco FT/IR-4600 Fourier transform infrared spectrometer with 40 measurements per one spectrum, at the measurement range between $4000 \mathrm{~cm}^{-1}$ and $400 \mathrm{~cm}^{-1}$.

\section{RESULTS AND DISCUSSION}

\section{Thermal properties}

Storage $\left(E^{\prime}\right)$ and loss $\left(E^{\prime \prime}\right)$ module obtained in DMA tests were plotted in Fig. 1. The glass transition tempera-

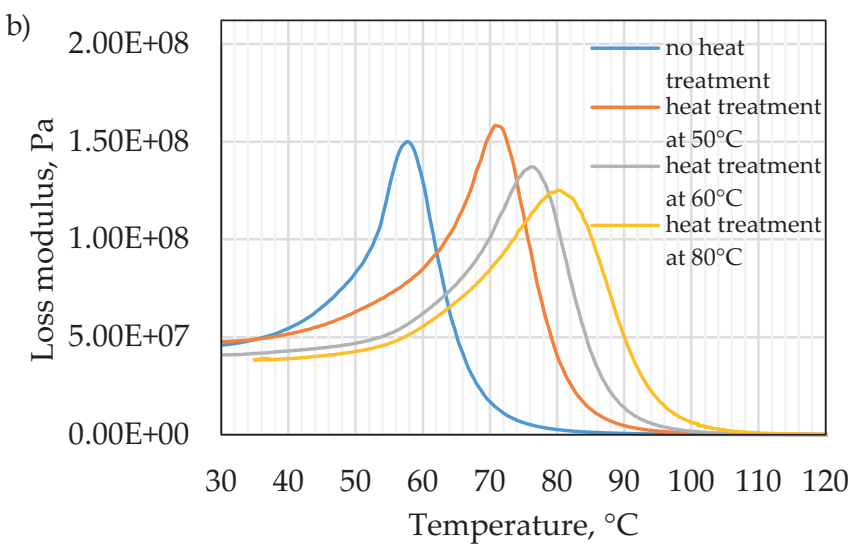

Fig. 1. Effect of the heat treatment at room temperature: 50,60 and $80^{\circ} \mathrm{C}$ on the DMA run: a) storage modulus $E^{\prime}$, b) loss modulus $E^{\prime \prime}$

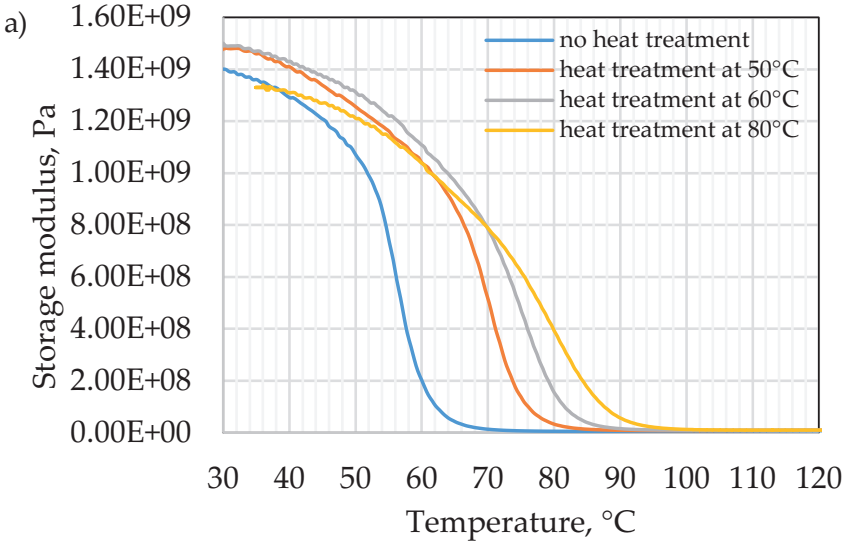


T a b l e 2. Glass transition temperature ranges obtained in DMA and DSC measurements of epoxy resin heated in four different temperatures

\begin{tabular}{l|c|c|c}
\hline \multicolumn{1}{c|}{ Heat treatment } & $\begin{array}{c}\text { Glass transition temperature } \\
\text { range, }{ }^{\circ} \mathrm{C}\end{array}$ & $T_{g \text { DMA }^{\prime}}{ }^{\circ} \mathrm{C}$ & 57.8 \\
\hline No heat treatment & $38.7-74.0$ & 71.0 & 67.9 \\
Heat treatment at $50^{\circ} \mathrm{C}$ & $44.4-87.4$ & 76.3 \\
Heat treatment at $60^{\circ} \mathrm{C}$ & $51.7-93.3$ & 80.3 \\
Heat treatment at $80^{\circ} \mathrm{C}$ & $51.9-99.9$ & 75.3 \\
\hline
\end{tabular}

ture ranges, as well as $T_{g \text { DMA }^{\prime}}$ are presented in Table 2, while storage modulus $E^{\prime}$ in ambient conditions is presented in Table 3. It is noticeably that for higher heat treatment temperature a shift of the storage modulus and loss modulus plots, versus higher temperature was noted, denoting a certain improvement of thermal stability, due to enhanced crosslinking of the resin. However, as far as $E^{\prime}$ in ambient conditions is concerned, its values for 50 and $60^{\circ} \mathrm{C}$ heat treatment temperature are higher than for $80^{\circ} \mathrm{C}$ and for no heat treatment samples.

The values of $T_{g \text { DSC }}$ are presented in Table 2 . Although the midpoints of glass transition regions obtained in DSC are slightly higher than values of $T_{g \text { DMA }}$ they confirm a similar trend, that is a relationship between the glass transition temperature ranges and the heat treatment temperature. It is known that the values of $T_{g \text { DMA }}$ are strongly dependent on measurement frequency. Thus higher values of $T_{g \text { DSC }}$ compared to $T_{g \text { DMA }}$ may be correlated to the DMA measurements condition, when the samples are submitted to sinusoidal changing deformation. It is not the case of DSC investigations, which may be treated as practically static [49, 57-59].

\section{Mechanical properties}

The tensile testing and the three-point bending testing results are presented in Table 4, where a relation between the heat treatment temperature and mechanical properties is visible.

The rise in heat treatment temperature leads to an increase of tensile strength $\sigma_{\mathrm{m}^{\prime}}$ maximal flexural stress $\sigma_{\mathrm{fm}^{\prime}}$ and of deformation $\varepsilon_{\mathrm{m}}$ and $\varepsilon_{\mathrm{fm}}$. A lower impact on elastic modulus in tensile $E_{t}$ and bending $E_{f}$ was noted moreover. The highest increase for the majority of mechanical properties was observed for the samples heated at $50^{\circ} \mathrm{C}$, compared to the non-heated samples. On the contrary, the value of elongation at break $\varepsilon_{b}$ remains practically constant, with a slight increase for samples treated at $60^{\circ} \mathrm{C}$.

The toughness $U_{\mathrm{TT}}$ exposes the highest value by the sample heated at $60^{\circ} \mathrm{C}$.

A significant difference in $U_{\mathrm{TT}}$ was found between the non-heated and thermally treated samples. The values for heated samples are higher than the result presented in [71] for pre-cured at $50^{\circ} \mathrm{C}$ for $4 \mathrm{~h}$ and post-cured at $70^{\circ} \mathrm{C}$ for $6 \mathrm{~h}$ epoxy resin.

The brittleness $B$ values indicate that materials without heat treatment and those heated in $80^{\circ} \mathrm{C}$ are generally more brittle comparing with heat treated at 50 and $60^{\circ} \mathrm{C}$ (Table 3). All brittleness values, likewise the thermal expansivity evaluated on the basis of Eq. (3), are most similar to styrene/acrylonitrile copolymer (SAN), among materials described in [69]. Although it is known that "brittleness is not an inverse of toughness" [72], a close

T a b l e 3. Storage modulus at ambient conditions $E^{\prime}$ obtained in DMA, brittleness $B$, linear isobaric thermal expansivity $\alpha_{\mathrm{L}}$ and impact strength $U_{\mathrm{C}}$ of epoxy resin heated in four different temperatures

\begin{tabular}{l|c|c|c|c}
\hline \multicolumn{1}{c|}{ Heat treatment } & $E^{\prime}, \mathrm{Pa}$ & $B, \% \cdot \mathrm{Pa} / 10^{10}$ & $\alpha_{\mathrm{L}^{\prime}}, 10^{-6} / \mathrm{K}$ & $U_{\mathrm{C}^{\prime}} \mathrm{J} / \mathrm{cm}^{2}$ \\
\hline No heat treatment & $1.35 \mathrm{E}+09$ & 1.38 & 108.5 & 1.84 \\
Heat treatment at $50^{\circ} \mathrm{C}$ & $1.45 \mathrm{E}+09$ & 1.21 & 106.7 & 2.04 \\
Heat treatment at $60^{\circ} \mathrm{C}$ & $1.46 \mathrm{E}+09$ & 1.12 & 105.6 & 1.93 \\
Heat treatment at $80^{\circ} \mathrm{C}$ & $1.34 \mathrm{E}+09$ & 1.30 & 107.7 & 1.98 \\
\hline
\end{tabular}

T a b l e 4. Mechanical properties of epoxy resin, by tensile and bending testing, heated in four different temperatures

\begin{tabular}{|c|c|c|c|c|c|c|c|c|c|}
\hline \multirow[b]{2}{*}{ Heat treatment } & \multicolumn{6}{|c|}{ Tensile testing } & \multicolumn{3}{|c|}{ Three-point bending } \\
\hline & $\begin{array}{c}E_{t} \\
\mathrm{GPa}\end{array}$ & $\begin{array}{c}\sigma_{\mathrm{m}} \\
\mathrm{MPa}\end{array}$ & $\begin{array}{c}\varepsilon_{\mathrm{m}} \\
\%\end{array}$ & $\begin{array}{c}\sigma_{\mathrm{b}} \\
\mathrm{MPa}\end{array}$ & $\begin{array}{l}\varepsilon_{\mathrm{b}} \\
\%\end{array}$ & $\begin{array}{c}U_{\mathrm{TT}} \\
\mathrm{J} / \mathrm{m}^{3} \cdot 10^{4}\end{array}$ & $\begin{array}{c}E_{f} \\
\mathrm{GPa}\end{array}$ & $\begin{array}{c}\sigma_{\mathrm{fm}} \\
\mathrm{MPa}\end{array}$ & $\begin{array}{l}\varepsilon_{\mathrm{fm}} \\
\%\end{array}$ \\
\hline No heat treatment & 2.3 & 52.7 & 3.7 & 25.4 & 6.1 & 213.7 & 3.0 & 100.6 & 4.3 \\
\hline Heat treatment at $50^{\circ} \mathrm{C}$ & 2.6 & 73.8 & 4.9 & 66.0 & 6.0 & 307.8 & 3.1 & 118.5 & 5.5 \\
\hline Heat treatment at $60^{\circ} \mathrm{C}$ & 2.4 & 74.2 & 5.3 & 66.3 & 6.7 & 358.5 & 3.1 & 124.4 & 5.8 \\
\hline Heat treatment at $80^{\circ} \mathrm{C}$ & 2.4 & 76.2 & 5.4 & 73.3 & 6.2 & 326.7 & 3.3 & 133.4 & 5.9 \\
\hline
\end{tabular}




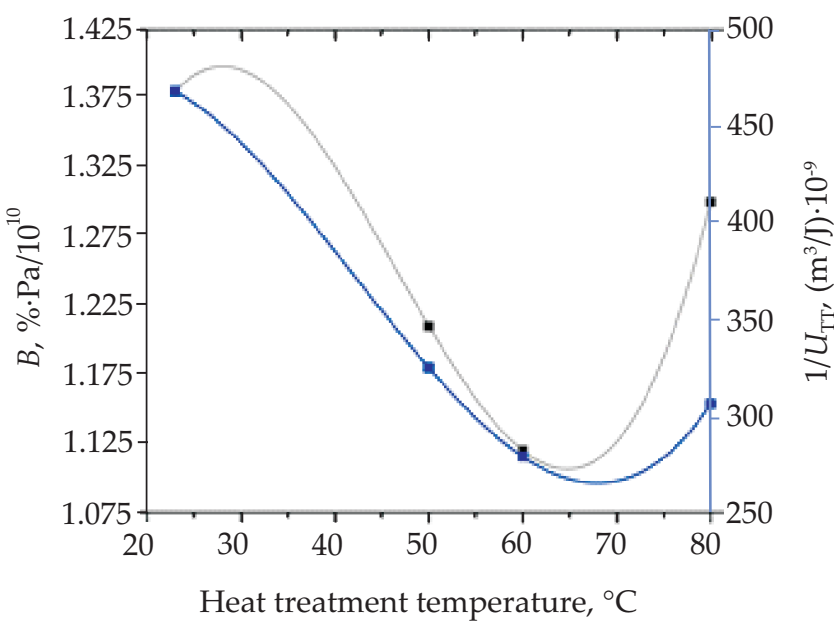

Fig. 2. The correlation between the brittleness $B$, the inverse of tensile toughness $U_{\mathrm{TT}}$ and the heat treatment conditions

correlation between the third degree polynomial fits of $B$ and $1 / U_{\mathrm{TT}}$ as functions of heat treatment temperature can be observed at Fig. 2.

Moreover, the Table 3 contains the values of $\alpha_{\mathrm{L}}$ calculated on the basis of brittleness. The obtained results indicate that the values provided for the epoxy resin in [70] are twice too low.

The values of Charpy impact strength $U_{C}$ for samples treated in different temperatures are presented in Table 3 . The values obtained for no-thermally treated samples are in accordance with [73]. A moderate effect of the heat treatment on $U_{C}$ was noted. The dependence of $U_{C}$ on $B$ is presented in Fig. 3. The evaluated points form the same line as $U_{\mathrm{C}}$ plot (representing the equation given by Brostow et al. in [69]), although transferred to higher values of impact strength. As it follows from Fig. 3, in a quasi linear domain of an impact/brittleness relationship, the comparable $U_{C}$ values of approximately $2 \mathrm{~J} / \mathrm{cm}^{2}$ correspond with $B$ values at the range between 1.1 and $1.4 \% \cdot \mathrm{Pa} / 10^{10}$.

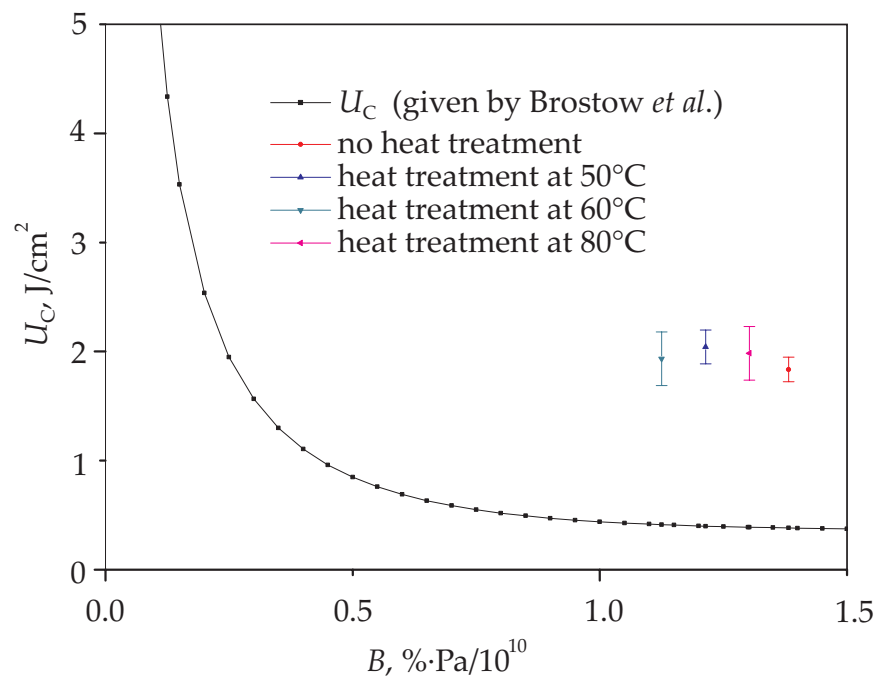

Fig. 3. The Charpy impact strength $U_{\mathrm{C}}$ as a function of brittleness $B$ for samples treated at various temperatures
The effect of heat treatment on the Shore D hardness is presented in Fig. 4 with corresponding standard errors. The results for resin/hardener mass ratios of $100: 30$, $100: 40$ and 100:50 are depicted on this figure. As it follows from the graph, a significant difference of hardness between non-heated and heated samples was noted, where an increase from Shore D $=55$ to approximately $73-83$ is probably be due to the substantial role of thermally stimulated cross linking of the epoxy resin, with the lowest hardener content. For the $100: 40$ samples, this increase between about 76 and 83 Shore $D$ values is much less evident, although it indicates an essential role of heat treatment by hardening this type of resin. Any improvement of hardness was noted for the ratio $100: 50$, i.e. the hardener content which exceeded the producer's recommendations.

\section{Density}

The effect of heat treatment on the density of samples with resin/hardener mass ratios of 100:30, 100:40 and 100:50 is presented in Fig. 5. The highest $\varrho$ values of approximately $1.181 \mathrm{~g} / \mathrm{m}^{3}$ to $1.186 \mathrm{~g} / \mathrm{m}^{3}$ were noted for the samples with the lowest hardener content, and the lowest density values, in the range between $1.154 \mathrm{~g} / \mathrm{m}^{3}$ and $1.158 \mathrm{~g} / \mathrm{m}^{3}$ for epoxy resins solidified by the highest hardener content. This effect may be due to various density of resin and hardener (see Table 1). As the applied hardener has a lower density, consequently the $100: 30$ samples reveal a higher density than the samples $100: 40$ and $100: 50$.

A slight rise in the density with the heat treatment was also noticed. The difference between the value of the unheated $100: 40$ sample and the one heated at $80^{\circ} \mathrm{C}$, referred to the density of the unheated sample, equals approximately $0.5 \%$. Although this change is almost invis-

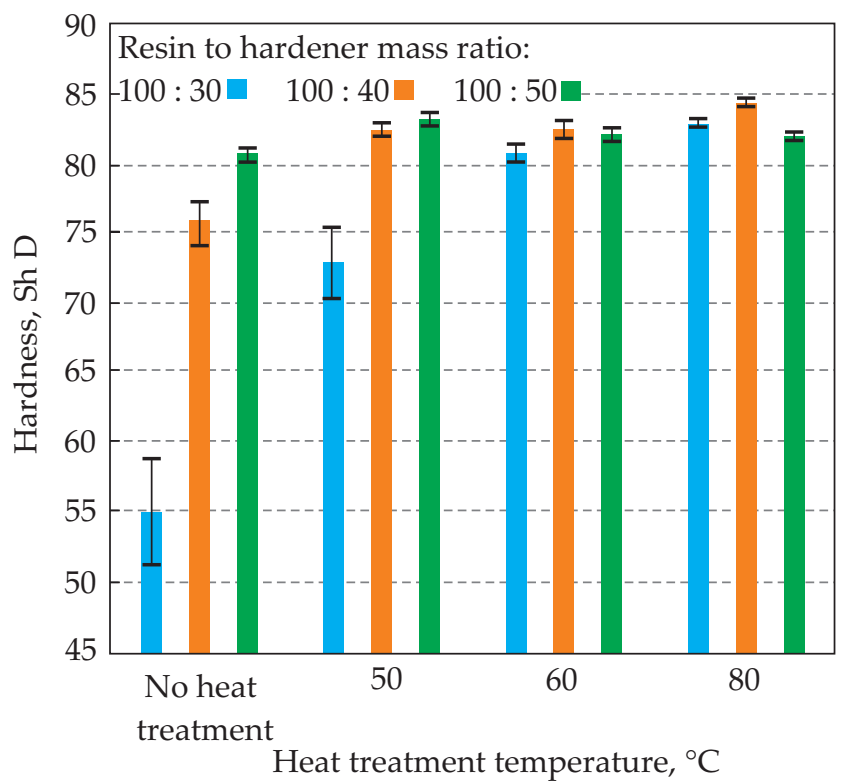

Fig. 4. Effect of thermal treatment and resin/hardener mass ratio on the Shore $\mathrm{D}$ hardness mean values 


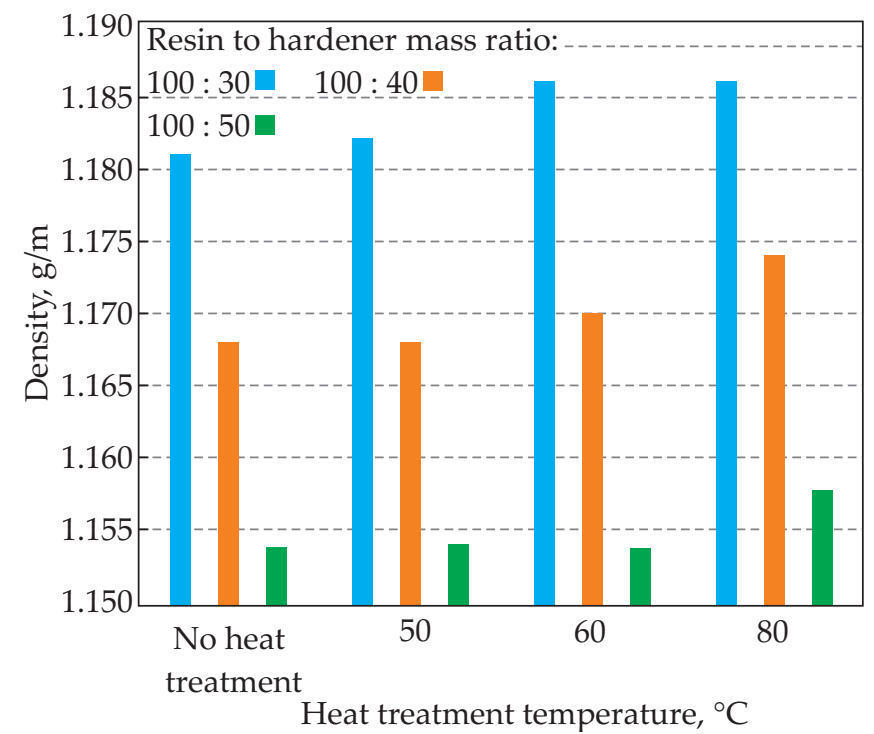

Fig. 5. The effect of thermal treatment and resin/hardener mass ratio on the density

ible in comparison to the one resulting from different mass ratios, it occurs for all resin/hardener concentrations.

\section{FT-IR}

The FT-IR spectra are presented in Fig. 6. As it may be seen, each of the four lines on the chart reveals the same course of peaks, characteristic for epoxy resin, namely at $3365,2925,2855,2314,1607,1507,1457,1241,1181,1035$, 828 and $559 \mathrm{~cm}^{-1}$. As no additional peaks was detected, a conclusion may be formulated that beside crosslinking no other changes in the chemical structure of the polymer network, during curing of the resin, are sufficiently significant to be observed on the FT-IR spectra.

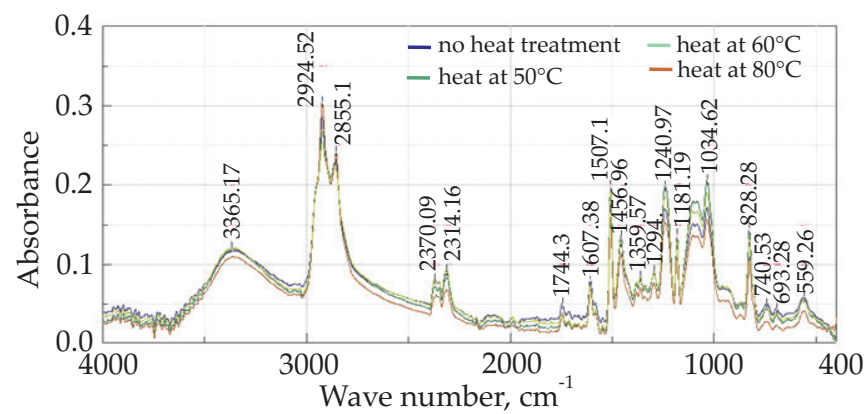

Fig. 6. The FT-IR spectra at a measurement range between $4000 \mathrm{~cm}^{-1}$ and $400 \mathrm{~cm}^{-1}$ for the epoxy samples with various heat treatment

\section{CONCLUSIONS}

A shift of the glass transition temperature regions versus higher values was due to thermal treatment induced improvement of the crosslinking, as found by DMA and DSC measurements. This effect, also apparent at higher density, hardness measurements, as well as tensile and flexural strength may support the idea of a correlation between chain topology, free volume, and the glass transition temperature $T_{g^{\prime}}$ as suggested by Kalogeras et al. in [74]. Free volume distribution can be determined according to the Voronoi-Delaunay approach, which combines molecular dynamics and Voronoi tessellation analysis. In order to achieve this goal, Delaunay simplices and Voronoi polyhedra are constructed for the set of points determined by the chain topology. For example, the application of Voronoi-Delaunay structural analysis, extracted for a linear chain polymer, led to the conclusion that the average volume of the Voronoi polyhedron around the particles of the polymer decreases with increasing length of the chain, resulting in a reduction of free volume [75].

By certain properties, such as elongation at break $\varepsilon_{b^{\prime}}$ toughness $U_{\mathrm{TT}}$ impact strength $U_{\mathrm{C}^{\prime}}$ storage modulus $E^{\prime}$ as well as inverse of brittleness $1 / B$ and inverse of linear isobaric thermal expansivity $1 / \alpha_{\mathrm{L}}$ higher values were observed for samples treated at $50^{\circ} \mathrm{C}$ or/and $60^{\circ} \mathrm{C}$, indicating a non-linear temperature dependence of properties at these thermal conditions. Moreover it may be suggested that the tendency to increase at this region (as in the case of $\sigma_{m}$ ) is balanced by an increasing tendency to crack.

In the case of an investigated material, it is not a general rule that the effect of heat treatment on brittleness $B$ is almost the same as on an inverse of toughness $1 / U_{\mathrm{TT}}$.

The examination of various resin/hardener ratios allowed on tracing the effect of heat treatment on the curing process. A lower mass fraction of the hardener than in 100:40 ratio (namely 100:30 ratio) results in lower crosslinking of the resin, although the resulting differences in hardness values may be equalized by the heat treatment of $60^{\circ} \mathrm{C}$ or higher.

On the contrary, no significant indication of the chemical modification due to the heat treatment of the epoxy resin, was found by the FT-IR analysis of the post heated samples.

\section{ACKNOWLEDGMENTS}

The Authors would like to thank Olga Mysiukiewicz, Mateusz Barczewski, Danuta Matykiewicz and Kinga Mencel from Polymer Division at Poznan University of Technology for their help with the DSC and DMA measurements.

The research was conducted in the framework of the project implemented in 2018-2019, entitled "The study of electrical conductivity as a function of fatigue of an aircraft composite material with defined strength properties' No GB/5/2018/209/2018/ DA funded by the Ministry of National Defense of the Republic of Poland. This research was also partly sponsored by the PUT grant 02/25/SBAD/4630.

\section{REFERENCES}

[1] Bhuvaneshwaran M., Sampath P.S., Sagadevan S.: Polimery 2019, 64, 93.

https://doi.org/10.14314/polimery.2019.2.2

[2] Oliwa R., Oleksy M., Oliwa J. et al.: Polimery 2019, 64, 290. 
https://doi.org/10.14314/polimery.2019.4.7

[3] Arasu P.M., Karthikayan A., Venkatachalam R.: Polimery 2019, 64, 504.

https://doi.org/10.14314/polimery.2019.7.6

[4] Jucha B., Kozioł M.: Composites Theory and Practice 2019, 19 (4), 135.

[5] Oliwa R., Heneczkowski M., Oleksy M.: Polimery 2015, 60, 167. https://doi.org/10.14314/polimery.2015.167

[6] Mossety-Leszczak B., Ostyńska P., Dutkiewicz M. et al.: Polimery 2013, 58, 212.

https://doi.org/10.14314/polimery.2013.212

[7] Oleksy M., Oliwa R., Heneczkowski M. et al.: Polimery 2012, 57, 228.

https://doi.org/10.14314/polimery.2012.228

[8] Krzyżak A., Kosicka E., Borowiec M. et al.: Materials 2020, 13 (6), 1364. https://doi.org/10.3390/ ma13061364

[9] Krzyżak A., Bemowski G., Szczepaniak R. et al.: "Safety and Reliability-Safe Societies in a Changing World", (Eds. Barros A., van Gulijk C., Haugen S. et al.), Taylor \& Francis Group, London 2018, p. 2093.

[10] Katunin A., Krukiewicz K., Herega A. et al.: Advances in Materials Science 2016, 16 (2), 32. https://doi.org/10.1515/adms-2016-0007

[11] Rośkowicz M., Smal T., Szrama S.: Scientific Journal of the Military University of Land Forces 2018, 188, 208. https://doi.org/10.5604/01.3001.0012.2509

[12] Mysiukiewicz O., Gospodarek B., Ławniczak P. et al.: Advances in Polymer Technology 2018, 37, 3542. https://doi.org/10.1002/adv.22138

[13] Oliwa R., Heneczkowski M., Oliwa J. et al.: Polimery 2017, 62, 658. https://doi.org/10.14314/polimery.2017.658

[14] Szeluga U., Pusz S., Kumanek B. et al.: Composites Part A: Applied Science and Manufacturing 2018, 105, 28. https://doi.org/10.1016/j.compositesa.2017.11.004

[15] Krzyżak A., Kucharczyk W., Gaska J. et al.: Composite Structures 2018, 202, 978.

https://doi.org/10.1016/j.compstruct.2018.05.018

[16] Ke J., Li X., Jiang S. et al.: Journal of $\mathrm{CO}_{2}$ Utilization 2018, 26, 302. https://doi.org/10.1016/j.jcou.2018.05.020

[17] Brostow W., Brozynski M., Datashvili T. et al.: Polymer Bulletin 2011, 67, 1671. https://doi.org/10.1007/s00289-011-0571-3

[18] Nazarpour-Fard H., Rad-Moghadam K., Shirini F. et al.: Polimery 2018, 63, 254. https://doi.org/10.14314/polimery.2018.4.1

[19] Rokicki G., Kowalczyk T., Kaczorowski M.: Polimery 2018, 63, 90. https://doi.org/10.14314/polimery.2018.2.2

[20] Murias P., Maciejewski H., Galina H.: European Polymer Journal 2012, 48, 769. https://doi.org/10.1016/j.eurpolymj.2012.01.009

[21] Dydek K., Boczkowska A., Latko-Durałek P. et al.: Journal of Composite Materials 2020. https://doi.org/10.1177/0021998320902227

[22] Dydek K., Latko-Durałek P., Boczkowska A. et al.: Composites Science and Technology 2019, 173, 110. https://doi.org/10.1016/j.compscitech.2019.02.007

[23] Khorasani M.G.Z., Silbernagl D., Szymoniak P. et al.: Polymer 2019, 164, 174.

https://doi.org/10.1016/j.polymer.2018.12.054

[24] Vu C.M., Sinh L.H., Nguyen D.D. et al.: Polymer Testing 2018, 71, 200.

https://doi.org/10.1016/j.polymertesting.2018.09.005

[25] Komorek A., Komorek Z., Krzyżak A. et al.: International Journal of Thermophysics 2017, 38, 128. https://doi.org/10.1007/s10765-017-2254-2

[26] Oliwa R., Oleksy M., Oliwa J. et al.: Polimery 2019, 64, 290. https://doi.org/10.14314/polimery.2019.4.7

[27] Śliwa R., Oleksy M., Heneczkowski M. et al.: Polimery 2015, 60, 667. https://doi.org/10.14314/polimery.2015.667

[28] Oliwa R., Oleksy M., Czech-Polak J. et al.: Journal of Fire Sciences 2019, 073490411983121. https://doi.org/10.1177/0734904119831211

[29] Oliwa R., Heneczkowski M., Oleksy M. et al.: Composites Part B: Engineering 2016, 95, 1. https://doi.org/10.1016/j.compositesb.2016.03.074

[30] Oliwa R., Oliwa J., Bulanda K. et al.: Polimery 2019, 64, 499. https://doi.org/10.14314/polimery.2019.7.5

[31] Koziol M., Jesionek M., Szperlich P.: Journal of Reinforced Plastics and Composites 2017, 36, 640. https://doi.org/10.1177/0731684416689144

[32] https://www.aircraftspruce.com/catalog/pdf/ mgs285tech.pdf (access date 30.11. 2019).

[33] Mphahlele K., Ray S.S., Kolesnikov A.: Composites Part B: Engineering 2019, 176, 107300.

https://doi.org/10.1016/j.compositesb.2019.107300

[34] Ahmadi Z.: Progress in Organic Coatings 2019, 132, 445. https://doi.org/10.1016/j.porgcoat.2019.04.003

[35] Urbaniak M.: Polimery 2018, 63, 18. https://doi.org/10.14314/polimery.2018.1.3

[36] Matykiewicz D., Dudziec B., Sterzyński T.: Polimery 2014, 59, 855. https://doi.org/10.14314/polimery.2014.855

[37] Murias P., Byczyński Ł., Maciejewski H. et al.: Journal of Thermal Analysis and Calorimetry 2015, 122, 215. https://doi.org/10.1007/s10973-015-4703-0

[38] Pusz S., Szeluga U., Nagel B. et al.: Polymer Composites 2014, 36, 336. https://doi.org/10.1002/pc.22948

[39] Molero G., Hung-Jue S.: Materials \& Design 2019, 182, 107965. https://doi.org/10.1016/j.matdes.2019.107965

[40] Jackson dos Santos D., Gouveia J.R., Philipp M. et al.: Polymer Testing 2019, 77, 105915.

https://doi.org/10.1016/j.polymertesting.2019.105915

[41] Yong-jin P., He X., Wu Q. et al.: Polyhedron 2018, in press. 
https://doi.org/10.1016/j.poly.2018.09.040

[42] Vališ D., Krzyżak A.: “Composite Materials Reliability Assessment and Comparison. Safety and Reliability of Complex Engineered Systems", Proceedings of the 25th European Safety and Reliability Conference, Zurich, Switzerland, 7-10 September 2015, p. 2119.

[43] Godzimirski J., Komorek A., Rośkowicz M.: Polimery 2008, 53, 737. https://doi.org/10.14314/polimery.2008.737

[44] Michel M., Ferrier E.: Construction and Building Materials 2020, 231, 117206. https://doi.org/10.1016/j.conbuildmat.2019.117206

[45] Touazi Y., Abdi A., Leshaf A., Khimeche K.: Progress in Organic Coatings 2020, 139, 105458. https://doi.org/10.1016/j.porgcoat.2019.105458

[46] Thiangpak P., Rodchanarowan A.: Materials Today: Proceedings 2018, 5, 9393. https://doi.org/10.1016/j.matpr.2017.10.115

[47] Jin N.J., Yeon J., Seung I. et al.: Construction and Building Materials 2017, 156, 933. https://doi.org/10.1016/j.conbuildmat.2017.09.053

[48] Staciwa P., SpychajT.: Polimery 2018, 63, 453. https://doi.org/10.14314/polimery.2018.6.6

[49] Sterzyński T., Tomaszewska J., Andrzejewski J. et al.: Composites Science and Technology 2015, 117, 398. https://doi.org/10.1016/j.compscitech.2015.07.009

[50] Halim A.S.I., Chan C.H. Kammer H.W.: Polymer Testing 2019, 79, 105994. https://doi.org/10.1016/j.polymertesting.2019.105994

[51] Furushima Y: Thermochimica Acta 2019, 677, 79. https://doi.org/10.1016/j.tca.2018.12.012

[52] Delucchi M., Castellano M., Vicini S. et al.: Progress in Organic Coatings 2018, 123, 20. https://doi.org/10.1016/j.porgcoat.2018.06.005

[53] Perret B., Schartel B., Stöß K. et al.: European Polymer Journal 2011, 47, 1081. https://doi.org/10.1016/j.eurpolymj.2011.02.008

[54] Liu C., Sun M., Zhang B. et al.: European Polymer Journal 2019, 121, 109304. https://doi.org/10.1016/j.eurpolymj.2019.109304

[55] Krzyżak A., Mucha M., Pindych D. et al.: Journal of KONES Powertrain and Transport 2018, 25, 217.

[56] Maity T., Samanta B.: Pigment \& Resin Technology 2015, 44 (1), 19. https://doi.org/10.1108/PRT-03-2014-0024

[57] Sterzyński T., Tomaszewska J., Piszczek K. et al.: Composites Science and Technology 2010, 70, 966. https://doi.org/10.1016/j.compscitech.2010.02.013
[58] Szyszkowska A., Czerniecka-Kubicka A., Pyda M.: Polymer Bulletin 2019, 76, 634. https://doi.org/10.1007/s00289-019-02702-5

[59] Drogoń A., Pyda M.: Polimery 2019, 64, 127. https://doi.org/10.14314/polimery.2019.2.6

[60] Urbaniak M.: Polimery 2017, 62, 394. https://doi.org/10.14314/polimery.2017.394

[61] Paszkiewicz S., Irska I., Piesowicz E. et al.: Polimery 2017, 62, 93. https://doi.org/10.14314/polimery.2017.093

[62] Karaer H., Kaya İ., Aydın H.: Polimery 2017, 62, 170. https://doi.org/10.14314/polimery.2017.170

[63] Hutchinson J.M., Román F., Cortés P. et al.: Polimery 2017, 62, 560 . https://doi.org/10.14314/polimery.2017.560

[64] Yang X., Wang Y., Li Y. et al.: Polimery 2017, 62, 576. https://doi.org/10.14314/polimery.2017.576

[65] Barczewski M., Andrzejewski J., Matykiewicz D. et al.: Polimery 2019, 64, 119. https://doi.org/10.14314/polimery.2019.2.5

[66] Balkan O., Demirer H.: Polymer Composites 2010, 31, 1285.

https://doi.org/10.1002/pc.20953

[67] Brostow W., Hagg Lobland H.E., Narkis M.: Journal of Materials Research 2006, 21 (9), 2422.

http://doi.org/10.1557/jmr.2006.0300

[68] Brostow W., Osmanson A.T.: Materials Letters: X 2019, 1, 100005. http://doi.org/10.1016/j.mlblux.2019.100005

[69] Brostow W., Hagg Lobland H.E.: Journal of Materials Science 2010, 45, 242. https://doi.org/10.1007/s10853-009-3926-5

[70] https://www.engineeringtoolbox.com/linear-expansion-coefficients-d_95.html (access data 01.04. 2020).

[71] Liu W., Wei B., Xu F.: Journal of Composite Materials 2016, 51, 2035. https://doi.org/10.1177/0021998316667541

[72] Brostow W., Hagg Lobland H.E., Narkis M.: Polymer Bulletin 2011, 67, 1697. https://doi.org/10.1007/s00289-011-0573-1

[73] Szeluga U., Kurzeja L., Galina H.: Polymer Bulletin 2008, 60, 555. https://doi.org/10.1007/s00289-008-0889-7

[74] Kalogeras I.M., Hagg Lobland H.E.: Journal of Materials Education 2012, 34, 69.

[75] Barbieri A., Prevosto D., Lucchesi M. et al.: Journal of Physics: Condensed Matter 2004, 16, 6609. https://doi.org/10.1088/0953-8984/16/36/026

Revised version 21 V 2020. 